\title{
Industrial Processing of Cooked Red Cabbage Pieces (Brassica Oleracea L.)
}

\author{
K. Kaack \\ Aarhus University, Kirstinebjergvej 10, and Aarslev, Denmark
}

*Corresponding Authors: K. Kaack, Aarhus University, Kirstinebjergvej 10, and Aarslev, Denmark

\begin{abstract}
Red cabbage may contribute to human health due to the contents of anthocyanins and the compounds released from these colorants that also may be very important for the quality characteristics of the processed red cabbage. The quality characteristics of the red cabbage produced from three industrial companies were equal because the factories are using a few cultivars and very ingredient composition and almost the same glass jar sizes. Red cabbage contains several odour compounds with very attractive odour characteristics that may be described further and applied for processing of several different foods using a variety of cuttings in combination with variation in brine composition on raw and processed cabbages. The contents of anthocyanins may improve the quality characteristics of cut and canned red cabbage foods significantly. Using a variety of red cabbage cultivars and variation in fertilizer composition, sowing times according to different sums of degree days may improve the quality characteristics of the red cabbage. The most value of canned red cabbage foods may be obtained using the variously health improving compounds with significantly and efficient properties as health promoting compounds.
\end{abstract}

Keywords: red cabbage, cooking, colour, harvest time and health promotion.

\section{INTRODUCTION}

The Danish food industries are processing cooked red cabbage and may appreciate that red cabbages are known as a very healthy vegetable because it convoys a variety of health benefits, depending on absorption and metabolic mechanisms that deliver anthocyanins and their bioactive metabolites to responsive red cabbage tissues [1]. Reseach in brassica species have shown that the anthocyanins from red cabbage have an inhibitory potential against digestive enzymes linked to obesity by inhibition of enzymes involved in the carbohydrate and lipid digestion [2]. These anthocyanins are well known for their toxic effects in both man and animals at high doses. In contrast at sub toxic doses, their hydrolytic and metabolic products acts as chemo protective agents against chemically induced carcinogens by blocking of the initiation of tumor developments in a variety of tissues, including liver, colon, mammary gland and pancreas [3]. Besides are those carcinogenic compounds known as glucosinolates that may result in blocking of Phase I and Phase II biotransformation enzymes and suppression of tumours by apoptosis [3,4,5]. Recent research have shown that the active anthocyanins in red cabbage have an inhibitory potential against digestive enzymes linked to obesity by inhibition against enzymes involved in carbohydrate and lipid digestion including $\alpha$-amylase, $\alpha$-glucosidase, and lipase [6]. Subtoxic doses of hydrolytic and metabolic compounds produced in the red cabbage tissue are supposed to act as bio protective agents towards chemically-induced carcinogens because they are blocking the tumor initiation in a variety of tissues, including liver, colon, mammary gland and pancreas as examples. These compounds exhibit their effects by inducing phase I and phase II enzymes, inhibiting the enzyme activation, modifying the steroid hormone contents and protection against significantly oxidative damage [3]. In that connection may the anthocyanins in red cabbage be considered as a very rich source of antioxidants as presented previously [7]. Cooking and blanching of red cabbage may result in severe reductions in the contents of aliphatic and indole glucosinolates by about certifive percent, respectively. The contents of ascorbic acid, total phenols, anthocyanins may be reduced significantly by causing $19,15,38$, and 28 percent losses during processing of these compounds in the red cabbage tissues. Besides may these compounds cause significantly reductions in glucosinolates and antioxidant related parameters in red cabbage [8]. And therefore are the aim of this research to study the changes in the contents of minerals, sugars, odour and anthocyanins during processing of red cabbage pieces. 


\section{MATERIALS AND METHODS}

The raw materials for processing of red cabbage in this research were obtained using cabbage heads from the cultivar 'Autoro' delivered from the three participating companies experienced in growing and processing of red cabbage. Company one used a blancher with shower head for supply of hot blanching water and companies two and three used steam blanchers with Archimedean screws. Company two did not use pumping at this stage of processing. Processing of red cabbage on the three industrial processing lines a1, a 2 and a3 were carried out according to normal practise at the factories using red cabbage heads from the cultivar 'Autoro'. Processing of red cabbage in this research included cutting of the cabbage leaves into pieces $<5 \mathrm{~mm}$ in length, cooking in an open nor closed pot, cooling of the cabbage pieces in cold water to $30^{\circ} \mathrm{C}$, packing in glass jars, size $530 \mathrm{~cm} 3$ jars, pasteurized at $80^{\circ} \mathrm{C}$ for $20 \mathrm{~min}$, cooled in cold water and stored at $12^{\circ} \mathrm{C}$ in a cooling cabinet until further analysis and sensory evaluation. The contents of dry matter were determined by drying of $200 \mathrm{~g}$ macerated samples at $80^{\circ} \mathrm{C}$ for twenty hours in a heating cabinet and drained weight was determined after actual storage time using a standard sieve (DIN 4188) with $2.5 \mathrm{~mm}$ sieve openings. The contents of potassium were measured using a ten times diluted standard solution with $0.55 \mathrm{~g} \mathrm{Ca}(\mathrm{OH}) 2$ and 54.75 $\mathrm{g} \mathrm{CaCl} 2,6 \mathrm{~g} \mathrm{H} 2 \mathrm{O} \mathrm{1-1}$. The obtained standard for calculation of the potassium contents in $\mathrm{g}$ potassium were: $\mathrm{g} \mathrm{L}-1=-0.0456 \mathrm{mv}-1.106 \mathrm{r}=0.99)$. Soluble solids were measured $\mathrm{w} / \mathrm{w}$ using a refractometer and titratable acid were determined by titration of macerated samples to $\mathrm{pH} 8.1$ using $0.1 \mathrm{~N} \mathrm{NaOH}$ in water. The anthocyanins were extracted using $0.01 \mathrm{w} / \mathrm{w} \% \mathrm{HCl}$ and the contents of anthocyanins were measured in duplicates at $530 \mathrm{~nm}$ using a Beckmann spectrophotometer. Measurement of surface colour included determination lightness $\mathrm{L}$, redness a and yellowness $\mathrm{b}$ using a a Hunter colorimeter. Firmnes were measured using a Kramer-shear cell packed with $175 \mathrm{~g}$ cabbage materials and stem velocity $20 \mathrm{~mm}$ min- 1 . The contents of volatiles and carbohydrates were extracted and measured as described previously [8]. And the contents of volatiles were collected in $500 \mathrm{~mL}$ distillate at $40^{\circ} \mathrm{C}$ obtained by disintegration og $2000 \mathrm{~g}$ cabbage with $2000 \mathrm{~g}$ distilled water in a blender followed by distillation of $500 \mathrm{ml}(12.5 \%)$ at $40{ }^{\circ} \mathrm{C}$ into from the mixtureof this mixture and distillation of volatiles were contents of volatiles were ocontents of odour compounds were collected by mixing of two $\mathrm{kg}$ cooked water with two kg distilled water using a Waring blender and transferred to a distillation column in order to collect $500 \mathrm{ml}$ red cabbage distillate containing 95 per cent of the volatiles applicable for sensory evaluation by sniff analysis in connection with sensory evaluation as described previously [9]. The size of the glass jars was $570 \mathrm{~cm} 3$ and they were packed with $280 \mathrm{~g}$ cooked cabbage and 250 $\mathrm{g}$ brine kept at $70^{\circ} \mathrm{C}$. Pasteurization was carried out in water baths kept at $80^{\circ} \mathrm{C}$ for $30 \mathrm{~min}$ and thereafter were the filled jars cooled in tap water at $60^{\circ} \mathrm{C}$ for $5 \mathrm{~min}$ and in cold water for $20 \mathrm{~min}$ before further analyses and evaluations were carried out. Drained weight was measured using a sieve (DIN $4188,2.5 \mathrm{~cm}$ ). The samples of canned red cabbage were stored at $15^{\circ} \mathrm{C}$ for six months and the average drained $(\mathrm{dw})$ weight decreased significantly linearly with cooking time $\mathrm{dw}=313-0.123 \mathrm{~min} \mathrm{r}=0.98$. The sensory quality characteristics of processed red cabbage were evaluated by an intensively trained panel of six women and three men age 22-25 year and trained for several years in sensory evaluation of several fruits and vegetables consumed in fresh or processed stage. Potassium were measured using an ion specific electrode (Corning) in samples diluted with a solution of $\mathrm{CaCl} 2$ and $\mathrm{Ca}(\mathrm{OH}) 2$ as described by the supplier of the equipment. The obtained equation for calculation of the potassium contents in $\mathrm{g}$ potassium g $1-1=-0.0456 \mathrm{mv}-1.106 \mathrm{r}=0.99$. The anthocyanins were extracted using 0.01 $\mathrm{w} / \mathrm{w} \% \mathrm{HCl}$ and the contents of anthocyanins were measured in duplicates (Brassica oleracea $\mathrm{L}$ ). Samples of the processed red cabbage were evaluated by an intensively trained panel of five women and two men age 22-25 trained in four years sensory evaluation of several fruits and vegetables consumed as fresh or processed stage.

\section{RESULTS AND DISCUSSION}

The average content of dry matter after cutting increased significantly from factory a1 to factory a3 after cutting and were at maximum for factory a2 after blanching (Table 1). The contents of dry matter increased significantly from factory a1 to factory a3 after cutting, were non significantly different after pumping and signifantly different between the factories after blanching. Soluble solids were at maximum for a3 after cutting and none significantly different in the other cases. Potassium was only significantly lowest after pumping and blanching for company a3. The contents of anthocyanin were significantly lowest for company a3 after cutting, highest after pumping for a3 and. highest for a2 after blanching. Previous studies of the effects of blanching showed that the losses were highest for 
Chinese cabbage $40 \%$ after 15 min of blanching, $27 \%$ for white cabbage, while the losses for Chinese white cabbage and red cabbage were 19.9 and $4.0 \%$, respectively [9]. Composition of the of raw cut cabbages processed by three companies (a1, a2, a3) processing red cabbage using the cultivar 'Autoro' with no specific pumping at factor

Table1. Composition of the raw cabbage from processing at the three industrial companies.

\begin{tabular}{|c|c|c|c|c|c|c|c|c|c|c|c|c|}
\hline Treatments & \multicolumn{3}{|c|}{$\begin{array}{l}\text { Dry matter } \\
\text { g } 100^{-1}\end{array}$} & \multicolumn{3}{|c|}{$\begin{array}{l}\text { Soluble solids } \\
\qquad{\mathrm{g} 100 \mathrm{~g}^{-1}}\end{array}$} & \multicolumn{3}{|c|}{$\begin{array}{l}\text { Potassium } \\
\mathrm{mg} 100 \mathrm{~g}^{-1}\end{array}$} & \multicolumn{3}{|c|}{$\begin{array}{l}\text { Anthocyanin } \\
\text { mg } 100 \mathrm{~g}^{-1}\end{array}$} \\
\hline After & $a_{1}$ & $a_{2}$ & $a_{3}$ & $\mathrm{a}_{1}$ & $\mathrm{a}_{2}$ & $a_{3}$ & $a_{1}$ & $a_{2}$ & $a_{3}$ & $a_{1}$ & $a_{2}$ & $a_{3}$ \\
\hline Cutting & $9.1 \mathrm{c}$ & $9.8 \mathrm{~b}$ & $10.1 \mathrm{a}$ & $5.4 b$ & $5.2 b$ & $6.8 \mathrm{a}$ & $2.4 \mathrm{a}$ & $2.4 \mathrm{a}$ & $2.1 \mathrm{a}$ & $17.0 \mathrm{a}$ & $17.3 \mathrm{a}$ & $16.5 b$ \\
\hline Pumping & $7.7 \mathrm{a}$ & & $7.5 \mathrm{a}$ & $4.3 \mathrm{a}$ & & $4.6 \mathrm{a}$ & $2.0 \mathrm{a}$ & & $1.7 \mathrm{~b}$ & $10.4 \mathrm{a}$ & & $14.1 \mathrm{~b}$ \\
\hline Blanching & $8.2 c$ & $9.1 \mathrm{a}$ & $8.7 \mathrm{~b}$ & $5.1 \mathrm{a}$ & $4.9 \mathrm{a}$ & $5.1 \mathrm{a}$ & $1.8 \mathrm{a}$ & $1.8 \mathrm{a}$ & $1.6 \mathrm{~b}$ & $9.8 \mathrm{c}$ & $14.7 b$ & $13.5 \mathrm{a}$ \\
\hline
\end{tabular}

This research included studies in the possibilities for application of blanched red cabbage juice as an ingredient by processing of red cabbage with the aim to improve the sensory properties of cooked red cabbage (Table 2). The contents of anthocyanin were not significantly different after cutting and significantly different between the factories after blanching. The contents of sugars were significantly different after cutting with maximum for $\mathrm{a}_{3}$ and non significance after pumping and blanching for $\mathrm{a}_{1}$ and $\mathrm{a}_{3}$. Total dry matter, anthocyanin, sugar and potassium in the blanching juices were significantly different between the three factoties at several points.

Table2. Contents of anthocyanins, sugar and dry matter on the three industrial processing lines.

\begin{tabular}{|l|c|c|c|c|c|c|l|c|c|c|}
\hline & \multicolumn{3}{|c|}{$\begin{array}{l}\text { Anthocyanin mg } 100 \\
\mathrm{~g}^{-1}\end{array}$} & \multicolumn{3}{|c|}{ Sugar g $100 \mathrm{~g}^{-1}$} & \multicolumn{3}{c|}{ Blanching juice composition. } \\
\hline Treatments & $\mathrm{a}_{1}$ & $\mathrm{a}_{2}$ & $\mathrm{a}_{3}$ & $\mathrm{a}_{1}$ & $\mathrm{a}_{2}$ & $\mathrm{a}_{3}$ & Compounds & $\mathrm{a}_{1}$ & $\mathrm{a}_{2}$ & $\mathrm{a}_{3}$ \\
\hline $\begin{array}{l}\text { After cut- } \\
\text { ting }\end{array}$ & $170 \mathrm{a}$ & $173 \mathrm{a}$ & $165 \mathrm{a}$ & $5.4 \mathrm{~b}$ & $5.2 \mathrm{~b}$ & $6.8 \mathrm{a}$ & $\begin{array}{l}\text { Total dry matter, } \mathrm{g} \\
100^{-1}\end{array}$ & $3.7 \mathrm{~b}$ & $4.7 \mathrm{a}$ & $3.9 \mathrm{~b}$ \\
\hline $\begin{array}{l}\text { After } \\
\text { pumping }\end{array}$ & $133 \mathrm{~b}$ & - & $141 \mathrm{a}$ & $4.3 \mathrm{a}$ & & $4.6 \mathrm{a}$ & $\begin{array}{l}\text { Anthocyanin, } \mathrm{mg} \\
100 \mathrm{~g}^{-1}\end{array}$ & $73.4 \mathrm{c}$ & $101.1 \mathrm{a}$ & $103.4 \mathrm{a}$ \\
\hline $\begin{array}{l}\text { After } \\
\text { blanching }\end{array}$ & $98 \mathrm{c}$ & $147 \mathrm{a}$ & $135 \mathrm{~b}$ & $5.1 \mathrm{a}$ & $4.9 \mathrm{a}$ & $5.1 \mathrm{a}$ & Sugar, mg $100 \mathrm{~g}^{-1}$ & $25.1 \mathrm{~b}$ & $35.7 \mathrm{a}$ & $19.4 \mathrm{c}$ \\
\hline $\begin{array}{l}\text { After can- } \\
\text { ning }\end{array}$ & $114 \mathrm{a}$ & - & $114 \mathrm{a}$ & $22.0 \mathrm{~b}$ & & $25.7 \mathrm{a}$ & $\begin{array}{l}\text { Potassium, mg } \\
100^{-1}\end{array}$ & $2.0 \mathrm{~b}$ & $2.1 \mathrm{~b}$ & $6.8 \mathrm{a}$ \\
\hline
\end{tabular}

After packing with sugar was the most important increases of minor importance, whereas the losses

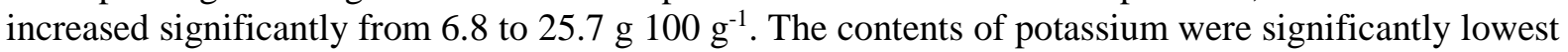
for company $a_{3}$ and similar for company $a_{1}$ and $a_{2}$. The average losses of potassium were about 25

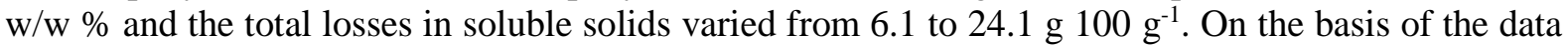
in table 2 it was concluded that processing resulted in significantly losses of dry matter, potassium, anthocyanin and sugars. After pumping on the three processing lines were the contents of dry matter reduced significantly. The contents of dry matter increased significantly both during blanching and

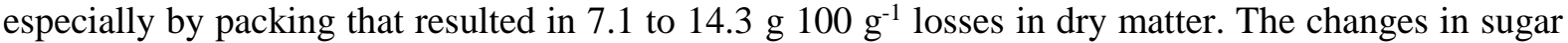
varied from 4.2 to 25.7 percent. Immediately after cutting of the cabbage heads were the contents of anthocyanin in the cut and packed cabbage heads non-significantly different between the three companies (Table 2). The contents of anthocyanin in the cabbage heads were significantly different after pumping and blanching, but not after packing. The contents of sugar were significantly different after cutting, but not in other cases. The differences in total dry matter, anthocyanin, sugar and potassium were significantly different. Some varieties accumulated more than 30 per cent acylated pigments, and the proportions of mono-acylated pigments may decrease with processing time [9] The data in table 3 shows that the contents of volatiles measured by gas chromatography changed significantly during processing with more than and the non-concentrated blanching juice that contained $14.8 \mathrm{mg} \mathrm{kg}^{-1}$ an-

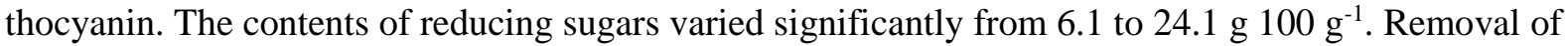
the odour compounds and variation in the soluble solids, acids and anthocyanins may increase the possibilities for application of blanching juice for improvement of the sensory quality characteristics of red cabbage. The odour of the volatile compounds that were eluted by gas chromatography was evaluated by members of the sensory panel. Seven compounds through the table with retention time $20,22,42,54,114,116,136$ and 165 min were odourless. The odour of compounds eluted after 25, $40,45,68,118$ and $144 \mathrm{~min}$ had an odour as freshly cut or raw grasses that may contribute signifi- 
cantly positively to the fresh odour of red cabbage heads. Odour as butter, vanilla, cinnamon 30,34 , $58,90,119,130$ and sweet cabbage may contribute positively to the odour of cooked red cabbage. On the contrary may compounds eluted after 84 and $85 \mathrm{~min}$ be characterized as strong off odours and 71, 75 and $130 \mathrm{~min}$ as raw cabbage and 144 was characterized as hay. The data in table 3 showed that red cabbage contained eight compounds without odour, five compounds with odour as fresh cut grass, four with odour as butter, one as vanilla, two as cinnamon, three as raw cabbage, one sweet cabbage, one sharp and one irony as found by the eight members of the intensively trained sensory panel with eight participants. The data in table 3 shows that red cabbage contained eight compounds without odour, five compounds with odour as fresh cut grass, four with odour as butter, one as vanilla, two as cinnamon, three as raw cabbage, one sweet cabbage, one sharp and one irony as found by the eight members of the intensively trained sensory panel with eight participants. Sensory analysis of the eluates by gas chromatography after 20,22, $42 \mathrm{~min}$, showed that the surface colours obtained from company $a_{2}$ encompassed thertien samples with surface colour $+\mathrm{a}_{2}$ red 18-23 and 25 samples from $+\mathrm{a}_{3}$ red 10-22. Besides occurred three synthetic samples in position $+\mathrm{a}_{3}$ red 10-12. The samples from $+\mathrm{a}_{3}$ had a more intensive colour in comparison to samples from company $+a_{2}$, that may be due to application red currant juices in both processing lines.

Table3. Odour compounds in cooked red cabbage with retention time and detector counts.

\begin{tabular}{|l|c|c|c|c|c|l|c|c|c|}
\hline Odour & Min & Raw & Blanched & Cooked & Min & Odour & Raw & Blanched & Cooked \\
\hline none & 20 & $1001 \mathrm{~b}$ & $2514 \mathrm{a}$ & $2522 \mathrm{a}$ & 75 & raw cabbage & $1436 \mathrm{a}$ & $491 \mathrm{c}$ & $691 \mathrm{~b}$ \\
\hline c & 22 & no & no & $624 \mathrm{a}$ & 84 & sharp & $744 \mathrm{~b}$ & $1339 \mathrm{a}$ & no \\
\hline fresh cut grass & 25 & $26 \mathrm{c}$ & $46 \mathrm{~b}$ & $102 \mathrm{a}$ & 85 & iron/tin & no & no & $439 \mathrm{a}$ \\
\hline butter & 30 & no & no & $909 \mathrm{a}$ & 90 & mustard & 23 & no & no \\
\hline vanilla & 34 & no & $835 \mathrm{~b}$ & $17618 \mathrm{a}$ & 114 & not known & $2937 \mathrm{a}$ & $752 \mathrm{~b}$ & no \\
\hline fresh cut grass & 40 & $448 \mathrm{a}$ & $27 \mathrm{~b}$ & no & 116 & none & no & no & 339 \\
\hline none & 42 & $563 \mathrm{a}$ & no & no & 118 & fresh grass & $432 \mathrm{a}$ & $172 \mathrm{~b}$ & no \\
\hline fresh cut grass & 45 & $814 \mathrm{a}$ & no & $68 \mathrm{~b}$ & 119 & $\begin{array}{l}\text { sweet cab- } \\
\text { bage }\end{array}$ & no & no & $1519 \mathrm{a}$ \\
\hline none & 54 & $272 \mathrm{c}$ & $783 \mathrm{~b}$ & $25283 \mathrm{a}$ & 130 & raw cabbage & $2303 \mathrm{a}$ & $516 \mathrm{~b}$ & $585 \mathrm{~b}$ \\
\hline cinnamon & 58 & $1503 \mathrm{~b}$ & $1843 \mathrm{a}$ & $710 \mathrm{c}$ & 136 & none & $471 \mathrm{c}$ & $560 \mathrm{~b}$ & $9264 \mathrm{a}$ \\
\hline fresh cut grass & 68 & $1464 \mathrm{a}$ & $738 \mathrm{~b}$ & $326 \mathrm{c}$ & 144 & hay & $144 \mathrm{~b}$ & $18.6 \mathrm{c}$ & $3312 \mathrm{a}$ \\
\hline red cabbage & 71 & no & no & $929 \mathrm{a}$ & 165 & none & $1025 \mathrm{a}$ & $803 \mathrm{~b}$ & $313 \mathrm{c}$ \\
\hline
\end{tabular}

The other compounds with decreasing level during processing included compounds with retention time 30, 42, 75, 90, 114, 118, 130 and $165 \mathrm{~min}$ and several compounds with increasing level during processing included $20,22,30,34,71$. The odour of the compounds eluted after 40, 42, 45, 68, 75, $114,118,130$ and 165 min was mainly characterized as freshly cut green leaves and the concentration decreased with elution time. Compounds with increasing level during processing included the compounds with retention time $20,22,25,30,34,54,71,81,85,116,119,136$ and 144 min. Table 4 shows the data from odour disruption of volatile compounds detected by the sensory panel by sniffing to the eluates at the end of the separation column as described previously by separation of volatiles in green beans [8]. The contents of compounds without odour were eluted after 20, 22, 114 and 116 min. The aim of this study was also to investigate the effects of different home cooking techniques, boiling, steaming, and stir-frying in red cabbage, on the levels of anthocyanins and phenolic compounds determined by high-performance liquid chromatography coupled with photodiode array and mass spectrometry detectors and on the antioxidant activity evaluated by and cellular antioxidant activity assays. The steaming technique resulted in significant increases in phenolic content in kale whereas in red cabbage it was significantly reduced. In the kale, steaming resulted in significant increases in antioxidant activity levels in all of the evaluation methods. In the red cabbage, boiling resulted in a significant increase in antioxidant activity using the abts assay. According to the CAA assay, the stir-fried sample displayed the highest levels of antioxidant activity [10]. 
Table4. Number of colour spots of red cabbage from company $a_{2}$ and $a_{3}$.

\begin{tabular}{|c|c|c|c|c|c|c|c|c|c|}
\hline \multirow{2}{*}{$\begin{array}{l}\text { Factory } \\
\mathrm{a}_{2}\end{array}$} & \multicolumn{7}{|c|}{$+\mathrm{a}_{2}$ red } & \multirow{2}{*}{$\begin{array}{l}\text { Synthetic } \\
\text { juice }\end{array}$} & \multirow{2}{*}{$\begin{array}{l}\text { Currant } \\
\text { juice } \\
\text { yes }\end{array}$} \\
\hline & $<18$ & 18-19 & $19-20$ & $20-21$ & $21-22$ & $22-23$ & Sum & & \\
\hline \multirow{2}{*}{ Red spot } & 1 & 3 & 2 & 4 & 2 & 1 & 13 & & \\
\hline & \multicolumn{7}{|l|}{$+\mathrm{a}_{3} \mathrm{red}$} & & \\
\hline$a_{3}$ & $10-12$ & $12-14$ & $14-16$ & 16-18 & $18-20$ & $20-22$ & & $10-12$ & yes \\
\hline Red spots & 2 & 6 & 3 & 5 & 4 & 1 & 25 & 3 & \\
\hline
\end{tabular}

Thermal degradation of individual glucosinolates within the plant matrix was studied. Red cabbage samples were heated at different temperatures for various times. To rule out the influence of enzymatic breakdown and to focus entirely on the thermal degradation of glucosinolates, myrosinase was inactivated prior to the thermal treatments. All identified glucosinolates degradation when heated at temperatures above $100{ }^{\circ} \mathrm{C}$. The indole glucosinolates 4-hydroxy-glucobrassicin and 4-methoxyglucobrassicin showed the highest degree of showed degradation, even at temperatures below $100{ }^{\circ} \mathrm{C}$. Kinetic parameters have been estimated for the degradation that could be described by first-order kinetics. At temperatures below $110{ }^{\circ} \mathrm{C}$ indole glucosinolates have a significant higher degradation rate constant as compared to aliphatic glucosinolates. The breakdown of 4-hydroxy-gluco-brassicin seems to consist of two parallel reaction pathways. Based on the proposed degradation kinetics and the estimated parameters, the degree of thermal degradation of all individual glucosinolates at standardized heating conditions (blanching, cooking and canning) was simulated. Glucosinolates are expected to be not very susceptible to thermal degradation during blanching conditions. Cooking will cause more thermal degradation to indole glucosinolates $(38 \%)$ as compared to aliphatic glucosinolates $(8 \%)$. Canning, the most severe heat treatment, will result in significant thermal degradation (73\%) of the total amount of glucosinolates [11].

Table5. Effects of processing at the two companies on quality characteristics.

\begin{tabular}{|c|c|c|c|c|c|c|}
\hline Company & Measures & Firmnes, $\mathrm{kg}$ & $\begin{array}{c}\text { Anthocyanin } \\
\mathrm{mg} 100 \mathrm{~g}^{-1}\end{array}$ & Lightness & Blueness & Redness \\
\hline $\mathrm{a}_{3}$ & Aerage & $109.0 \mathrm{a}$ & $35.5 \mathrm{a}$ & $17.4 \mathrm{a}$ & $15.0 \mathrm{a}$ & $-0.5 \mathrm{~d}$ \\
\hline $\mathrm{a}_{3}$ & Std. dev. & $29.7 \mathrm{c}$ & $8.49 \mathrm{~b}$ & $1.2 \mathrm{~d}$ & $2.8 \mathrm{~d}$ & $0.9 \mathrm{a}$ \\
\hline $\mathrm{b}_{2}$ & Average & $9.7 \mathrm{c}$ & $35.9 \mathrm{a}$ & $15.9 \mathrm{~b}$ & $12.7 \mathrm{~b}$ & -0.9 \\
\hline $\mathrm{b}_{2}$ & Std. dev. & $35.5 \mathrm{~b}$ & $12.9 \mathrm{c}$ & $4.4 \mathrm{c}$ & $3.7 \mathrm{c}$ & $1.0 \mathrm{c}$ \\
\hline
\end{tabular}

A previous study aimed to evaluate the anthocyanin pigment contents and profiles from seven red cabbage cultivars at two maturity stages eight weeks apart regarding their color characteristics and behavior under acidic and neutral $\mathrm{ph}$. The contents of anthocyanin concentrations ranged from 1111 to $1780 \mathrm{mg}$ cynidin-3-glucoside in $100 \mathrm{~g}$ dry matter and the contents did not increase further with growing time new [12]. Cultivar and maturation affected the pigment profile. Some varieties accumulated $>30 \%$ of diacylated pigments, and proportions of monoacylated pigments decreased with time. Extracts from selected varieties at first harvesting time produced colors similar to the extracts from the second harvest with higher proportion of diacylation. Cultivar selection and maturation affected color and stability of red cabbage extracts at different $\mathrm{pH}$ values [13].

Table6. Average of quality characteristics for samples from factory $a_{2}$ and $a_{3}(n=24)$

\begin{tabular}{|c|c|c|c|c|c|c|c|c|c|c|}
\hline & $\begin{array}{c}\text { Firm- } \\
\text { ness, kg }\end{array}$ & $\begin{array}{c}\text { Antho- } \\
\text { cyanine } \\
\mathrm{mg} 100 \mathrm{~g}^{-1}\end{array}$ & $\begin{array}{c}\text { Light- } \\
\text { ness } \\
\text { L } \\
\end{array}$ & $\begin{array}{c}\text { Green- } \\
\text { ness } \\
\text { a } \\
\end{array}$ & $\begin{array}{c}\text { Yellow- } \\
\text { ness } \\
\text { b }\end{array}$ & $\begin{array}{c}\text { Firm- } \\
\text { ness } \\
\text { kg } \\
\end{array}$ & $\begin{array}{c}\text { Antho- } \\
\text { cyanine } \\
\text { mg } 100 \mathrm{~g}^{-1}\end{array}$ & $\begin{array}{c}\text { Light- } \\
\text { tens } \\
\text { L } \\
\end{array}$ & $\begin{array}{c}\text { Green- } \\
\text { ness a } \\
\mathrm{a} \\
\end{array}$ & $\begin{array}{c}\text { Yellow- } \\
\text { ness } \\
\text { b }\end{array}$ \\
\hline & \multicolumn{5}{|c|}{ Factory $\mathrm{a}_{2}$} & \multicolumn{5}{|c|}{ Factory $a_{3}$} \\
\hline Avg. & 119.6 & 33.0 & 17.6 & 16.2 & 0.1 & 202.4 & 36.1 & 18.6 & 20.2 & -1.4 \\
\hline Std. & 24.8 & 6.8 & 1.0 & 2.4 & 0.5 & 47.7 & 4.5 & 0.8 & 1.4 & 0.3 \\
\hline 23 & 864 & 92 & 0 & 59 & 4 & 20 & 948 & 1 & 29 & 4 \\
\hline 1 & 243 & 4 & 0 & 11 & 0 & 2 & 446 & 0 & 2 & 0 \\
\hline
\end{tabular}

The data in table 6 shows the average of quality characteristics of canned red cabbage at factory $\mathrm{a}_{2}$ and $a_{3}$ by increasing and constant firmness, respectively. The average and standard deviations are typically for the processed samples from the two companies. It may be remarked that there occur significantly differences in yellowness of slices from the two companies. Humans are unable to synthesize L-ascorbic acid (1-aa), ascorbate, vitamin $\mathrm{C}$, and are thus entirely dependent upon dietary sources to 
meet the needs. In both plant and animal metabolism, the biological functions of 1-ascorbic acid are centered on the antioxidant properties of this molecule. Considerable evidence has been accruing in the last two decades of the importance of 1-aa in protecting not only the plant from oxidative stress, but also mammals from various chronic diseases that have their origins in oxidative stress. Evidence suggests that the plasma levels of l-aa in large sections of the population are sub-optimal for the health protective effects of this vitamin [13]. During cooking and blanching are the glucosinolates degraded according to first order kinetics with rate constants that varied between four to twenty fold between the vegetables [14]. Previous research showed that blanching of red cabbage resulted in significantly reductions in phenols, monomeric anthocyanins, ferric reducing ability power, oxygen-radical absorbance and ascorbic acid and soluble sugar contents [15]. Boiling resulted in less extensive reductions, while steaming caused reduced phenols and soluble sugars. However, significant reductions were found for monomeric anthocyanins and ascorbic acid. In general were losses accounted for in the processing waters, however the losses in total monomeric anthocyanins were not fully recovered, indicating degradation. Total glucosinolates were severely affected by processing, with degradation of 64, 38 and 19 percent in blanched, boiled and steamed red cabbage while aliphatic and indole glucosinolates were similarly affected and the lost parts were partially recovered in the processing water [15]. The data in table 7 shows the significantly differences in the contents of anthocyanin between the three cultivars and throughout the picking period for 'Autoro'. The three columns in the right part of table 6 shows that the red cabbage firmness decreased significantly and linearly with the blanching time. The contents of anthocyanin of the red cabbage cultivars measured from medium September to medium December showed significantly different contents of anthocyanin from 51 to $100 \mathrm{mg} 100 \mathrm{~g}^{-1}$, whereas the contents of dry matter varied significantly between months (Table 7). The average drained weight (Dw) decreased significantly linearly with cooking time $\mathrm{Dw}=313-0.123 \mathrm{~min} . \mathrm{r}=0.98$ and the average firmness decreased exponentially with cooking time. Until quite recently, little focus has been given to improving the laa-metabolism content of plant foods, either in terms of the amounts present in commercial crop varieties, or in minimizing losses prior to ingestion. Further, while 1-aa biosynthesis in animals was elucidated in the 1960s, it is only very recently that distinct biosynthetic routes for plants have been proposed. The characterization of this new pathway will undoubtedly provide the necessary focus and impetus to enable fundamental questions on plant 1-aa metabolism to be resolved. Table7. Processing of red cabbage pieces using cabbage heads from three cultivars.

\begin{tabular}{|c|c|c|c|c|c|c|c|}
\hline Cultivar & Picking & Anthocyanin & Dry matter & Anthocyanin & $\ln \mathrm{c}$ & $\mathrm{b}$ & $\mathrm{r}$ \\
\hline & Date & $\mathrm{mg} 100 \mathrm{~g}^{-1}$ & g $100 \mathrm{~g}-{ }^{1}$ & $\mathrm{mg} / 100 \mathrm{~g} \mathrm{dm}$ & & & \\
\hline Marne Sep. & $13^{\text {th }} \mathrm{Sep}$ & $51 \mathrm{a}$ & $2.57 \mathrm{~b}$ & $1984 \mathrm{e}$ & $7.44 a$ & $-0.95 a$ & $0.95 \mathrm{a}$ \\
\hline Ruby Perfec. & $"$ & $51 \mathrm{f}$ & $3.23 a$ & $1578 \mathrm{f}$ & $6.39 \mathrm{c}$ & $-0.84 \mathrm{~b}$ & $0.99 \mathrm{a}$ \\
\hline Autoro & $27^{\text {th }} \mathrm{Sep}$ & $126 \mathrm{a}$ & $3.22 \mathrm{a}$ & $3913 a$ & $6.15 b$ & $-0.70 \mathrm{c}$ & $0.97 \mathrm{a}$ \\
\hline ” & $11^{\text {th }} \mathrm{Oct}$ & $99 \mathrm{~d}$ & $2.95 \mathrm{a}$ & $3356 c$ & $6.70 \mathrm{~b}$ & $-0.69 \mathrm{c}$ & $0.94 \mathrm{a}$ \\
\hline$"$ & $20^{\text {th }}$ Nov & $121 b$ & $3.06 \mathrm{a}$ & $3954 a$ & $6.10 \mathrm{~d}$ & $-0.65 c$ & $0.96 a$ \\
\hline$"$ & $28^{\text {th }}$ Nov & $111 \mathrm{c}$ & $3.05 a$ & $3639 b$ & $6.10 \mathrm{e}$ & $-0.59 \mathrm{~d}$ & $0.96 a$ \\
\hline$"$ & $10^{\text {th }}$ Dec & $87 \mathrm{e}$ & $3.19 \mathrm{a}$ & $2727 d$ & & & \\
\hline$"$ & $13^{\text {th }}$ Dec & $110 \mathrm{c}$ & $3.06 \mathrm{a}$ & $3595 b$ & & & \\
\hline Avg. & & 118 & 3.04 & 3093 & 6.48 & -0.74 & 0.96 \\
\hline
\end{tabular}

This review focuses on the role of 1 -aa in metabolism and the latest studies regarding its biosynthesis, tissue compart metallization, turnover and catabolism. These relationships are considered in relation to the potential to improve the 1-aa test content of crops. Finally the factors that determine the bioavailability of l-aa test and how it may be improved are considered, as well as the most important future research needs [16]. During the food production chain from sowing, picking, storage and processing may the composition of glucosinolates change significantly. Blanching and cooking of vegetables led to considerable $(\mathrm{P}<0.05)$ losses of total glucosinolates from 2.7 to $30.0 \%$ and from 35.3 to $72.4 \%$, respectively. No systematic changes in total glucosinolates were found in the vegetables that 
were blanched, frozen and stored for $48 \mathrm{~h}$. The highest concentration of cancer-protective compounds, such as aliphatic and indole glucosinolates were found in Brussels sprouts (sinigrin and glucobrassicin) and in broccoli (glucoraphanin) [12]. The average of quality characteristics of samples of red cabbage processed at factory $\mathrm{a}_{2}$ and $\mathrm{a}_{3}$ showed significantly differences between and within and every property that occur because of the variation in maturity and development in the cabbage heads. Conventional cooking did not affect aliphatic glucosinolates significantly, while the indole glucosinolates decreased to a higher extent [13]. A large variation of the glucosinolate contents has been found previously by [14]. These results show that all cooking treatments, except steaming, caused significant losses of chlorophyll and vitamin $\mathrm{C}$ and significant decreases of total soluble proteins and soluble sugars. Total aliphatic and indole glucosinolates were significantly modified by all cooking treatments but not by steaming. In general, the steaming led to the lowest loss of total glucosinolates, while stir-frying and stir-frying/boiling presented the highest losses. Stir-frying and stirfrying/boiling may be the two most popular methods for most homemade dishes in that may cause great losses of chlorophyll, soluble protein, soluble sugar, vitamin $\mathrm{C}$, and glucosinolates, but the steaming method appears to be the best in retention of the nutrients in cooking broccoli. The various methods used by processing of red cabbage may result in severe significantly reductions of bioactive compounds including carotenoids, anthocyanins and phenolic compounds [15].

Table8. Drained weight and firmness of cultivars in dependence of cooking time.

\begin{tabular}{|l|c|c|c|c|c|c|c|c|c|c|c|c|c|}
\hline Cultivar & No & \multicolumn{10}{|c|}{ Cooking time, min } \\
\hline & & \multicolumn{10}{|c|}{ Drained weight, g $100 \mathrm{~g}^{-1}$} & \multicolumn{7}{|c|}{ Firmness, kg } \\
\hline & & 20 & 30 & 40 & 50 & 60 & Avg. & 20 & 30 & 40 & 50 & 60 & Avg. \\
\hline Marne & 1 & $307 \mathrm{~b}$ & $308 \mathrm{~b}$ & $305 \mathrm{~b}$ & $310 \mathrm{~b}$ & $305 \mathrm{a}$ & $307 \mathrm{a}$ & $103.7 \mathrm{a}$ & $67.7 \mathrm{~b}$ & $42.5 \mathrm{c}$ & $42.0 \mathrm{~d}$ & $37.7 \mathrm{e}$ & $58.7 \mathrm{~b}$ \\
\hline Ruby Perf. & 1 & $311 \mathrm{a}$ & $314 \mathrm{a}$ & $308 \mathrm{a}$ & $306 \mathrm{c}$ & $305 \mathrm{a}$ & $309 \mathrm{a}$ & $48.0 \mathrm{a}$ & $34.3 \mathrm{~b}$ & $27 . \mathrm{c} 0$ & $21.6 \mathrm{~d}$ & $19.3 \mathrm{e}$ & $30.1 \mathrm{f}$ \\
\hline Autoro & 1 & $309 \mathrm{~b}$ & $304 \mathrm{~b}$ & $310 \mathrm{a}$ & $314 \mathrm{a}$ & $308 \mathrm{a}$ & $309 \mathrm{a}$ & $60.7 \mathrm{a}$ & $44.3 \mathrm{~b}$ & $33.7 \mathrm{c}$ & $32.3 \mathrm{~d}$ & $28.3 \mathrm{e}$ & 39.9 \\
\hline$“$ & 2 & $311 \mathrm{a}$ & $308 \mathrm{~b}$ & $311 \mathrm{a}$ & $306 \mathrm{c}$ & $307 \mathrm{a}$ & $308 \mathrm{a}$ & $108.0 \mathrm{a}$ & $70.7 \mathrm{~b}$ & $70.7 \mathrm{~b}$ & $51.7 \mathrm{c}$ & $48.3 \mathrm{~d}$ & $69.9 \mathrm{a}$ \\
\hline$“$ & 1 & $312 \mathrm{a}$ & $312 \mathrm{a}$ & $308 \mathrm{a}$ & $309 \mathrm{c}$ & $306 \mathrm{a}$ & $309 \mathrm{a}$ & $78.3 \mathrm{a}$ & $56.7 \mathrm{~b}$ & $49.0 \mathrm{c}$ & $43.3 \mathrm{~d}$ & $38.7 \mathrm{e}$ & $53.2 \mathrm{~d}$ \\
\hline$“$ & 2 & $312 \mathrm{a}$ & $308 \mathrm{~b}$ & $309 \mathrm{a}$ & $307 \mathrm{c}$ & $308 \mathrm{a}$ & $309 \mathrm{a}$ & $85.3 \mathrm{a}$ & $57.7 \mathrm{~b}$ & $49.7 \mathrm{c}$ & $44.7 \mathrm{~d}$ & $42.3 \mathrm{e}$ & $55.9 \mathrm{c}$ \\
\hline$“$ & 1 & $308 \mathrm{~b}$ & $311 \mathrm{a}$ & $308 \mathrm{a}$ & $301 \mathrm{~d}$ & $304 \mathrm{~b}$ & $306 \mathrm{a}$ & $67.8 \mathrm{a}$ & $46.7 \mathrm{~b}$ & $40.0 \mathrm{c}$ & $37.3 \mathrm{~d}$ & $32.0 \mathrm{e}$ & $44.7 \mathrm{e}$ \\
\hline$“$ & 2 & $315 \mathrm{a}$ & $312 \mathrm{a}$ & $312 \mathrm{a}$ & $305 \mathrm{e}$ & $302 \mathrm{~b}$ & $309 \mathrm{a}$ & $72.3 \mathrm{a}$ & $57.0 \mathrm{~b}$ & $52.3 \mathrm{c}$ & $43.7 \mathrm{~d}$ & $41.3 \mathrm{e}$ & $53.3 \mathrm{~d}$ \\
\hline
\end{tabular}

Cooking techniques may improve the levels of bioactive compounds and antioxidant activity in red cabbage. Blanching and frozen storage of cauliflower resulted in significantly decreases in aliphatic and indole glucosinolates by 31 and 37 per cent and the contents of 1-ascorbic acid decreased 19 per cent, total phenols 15 , whereas anthocyanins were reduced 28 per cent. The effect of thermal treatment of glucosinolates and antioxidant-related parameters in red cabbage was found by [9]. The cooking water from the normal processing of red cabbage were rich in anthocyanins, soluble solids and organic acids and may generally be used for cooking of red cabbage instead of using pure water as

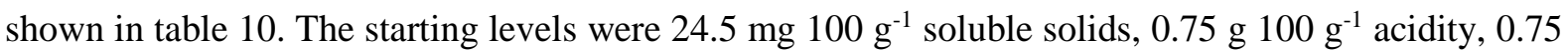
and anthocyanin $10.9 \mathrm{mg} 100 \mathrm{~g}^{-1}$. The results from nine more cooking are shown in table 10. Anthocyanin in cooking water increased from zero to $38.8 \mathrm{mg} 100 \mathrm{~g} \mathrm{~g}^{-1}$ and shows that the soluble solids increased from 24.5 to $26.5 \mathrm{mg} 100 \mathrm{~g} \mathrm{~g}^{-1}$, acidity increased from 0.75 to $0.79 \mathrm{~g} 100 \mathrm{~g}^{-1}$, anthocyanin from 10.9 to $18.4 \mathrm{mg} 100 \mathrm{~g}^{-1}$, lightness and greenness decreased whereas yellowness, $\Delta \mathrm{E}$ and firmness increased significantly and $\mathrm{pH}$ was constant. After nine cooking were soluble solids and anthocyanin in

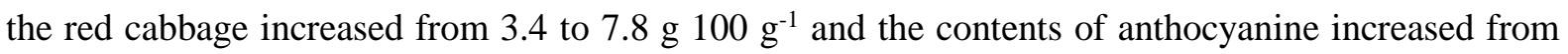

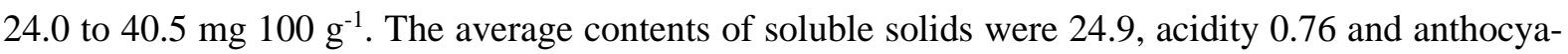

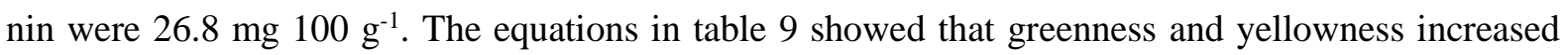
with the levels of acetic acid in the produced red cabbage and that firmness decreased with processing time. The contents of anthocyanin and yellowness decreased and increased with processing time, respectively. 
Table9. Changes in quality characteristics including acetic acid, soluble solids and processing time.

\begin{tabular}{|l|l|l|l|}
\hline Firmness $=100.8-16.5$ acetic acid & 0.81 & $\ln (\mathrm{kg})=7.76-0.72 \ln (\mathrm{min}+1)-0.012 \mathrm{~min}$ & 0.97 \\
\hline $\mathrm{a}=5.1+6.9$ acetic acid & 0.96 & Anthocyanin $=42.3-0.17 \mathrm{~min}$ & 0.93 \\
\hline $\mathrm{b}=-1.33+2.2$ acetic acid & 0.99 & Yellowness $=-0.40+0.0189 \mathrm{~min}$ & 0.80 \\
\hline $\mathrm{kg}=139.7-1.27$ soluble solids & 0.95 & & \\
\hline
\end{tabular}

Increasing cooking time from 10 to 60 min did not affect the contents sugar, $\mathrm{pH}$ or acetic acid in the red cabbage, whereas anthocyanin and firmness decreased significantly with the cooking time. It was found that blanching and cooking of the vegetables led to significantly losses of total glucosinolates from 2.7 to 30.0 per cent and from 35.3 to 72.4 per cent, respectively [16]. The contents of cabbage and lightness were not affected by increasing cooking time, while greenness decreased and yellowness increased significantly. The effects of thermal treatment on glucosinolates and antioxidantrelated parameters in red cabbage are described previously [9]. As pointed out will blanching and cooking of red cabbage result in severe reductions of aliphatic and indole glucosinolates by 31 and 37 percent and the contents of ascorbic acid, total phenols, anthocyanins by blanching [17]. The contents of glucosinolates may be classified as aliphatic, aromatic, omega-methylthioalkyl and heterocyclic compounds [3]. Studies in the effects of blanching, cooking and canning on the contents of eight glucosinolates showed that the rate of degradation was lowest after blanching, medium after cooking and maximum after canning. [17]. The glucosinolates have been described as responsible for the characteristic flavour and odour compounds in red cabbage foods [18]. That are because these compounds are released from the red cabbage heads due to myrosinase activity and enzymatic hydrolysis of the [19]. The products of these intermediate compounds in dependence of $\mathrm{pH}$ and substrate availability of ferrous ions [15]. Carisa; Mercadante, Adriana. Optimization of cooking techniques may improve the levels of bioactive compounds and antioxidant activity in red cabbage. The effects of domestic processing affect the occurrence of glucosinolates randomly [20], 21], whereas the industrial processes has been less studied $[22,23,24]$ and it is generally assumed that the responsible dietary constituents includes vitamins, minerals, dietary fibre, polyphenols and polyphenolics. The next experiment with cooking of red cabbage were carried out by transfer in two series using from 0 to 900 and from 900 to $0 \mathrm{~g}$ processing water. The contents of anthocyanin increased significantly from zero to $38.8 \mathrm{mg} 100 \mathrm{~g}$ ${ }^{1}$ using the extra supply of the compounds during processing. The contents of soluble solids, acidity

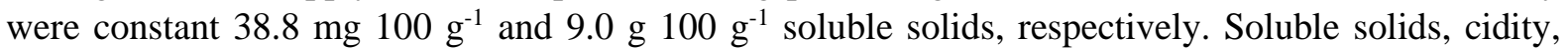
lightness, $\mathrm{pH}$ were constant while anthocyanin in the processed cabbage increased significantly. Blueness, redness, $\Delta \mathrm{E}$ and the contents The contents of

Table10. Data from processing of red cabbage pieces by reusing of the cooking water.

\begin{tabular}{|c|c|c|c|c|c|c|c|c|c|c|}
\hline $\begin{array}{c}\text { Antho- } \\
\text { cyanin } \\
\text { mg } 100 \mathrm{~g}^{-1}\end{array}$ & $\begin{array}{c}\text { Soluble } \\
\text { solids } \\
\mathrm{g} 100 \mathrm{~g}^{-1}\end{array}$ & $\begin{array}{c}\text { Acidity } \\
\mathrm{g} 100 \mathrm{~g}^{-1}\end{array}$ & $\begin{array}{c}\text { Light- } \\
\text { ness }\end{array}$ & $\begin{array}{c}\text { Antho- } \\
\text { cyanin } \\
\mathrm{mg} 100 \mathrm{~g}^{-1}\end{array}$ & $\begin{array}{c}\text { Blue- } \\
\text { ness }\end{array}$ & $\begin{array}{c}\text { Red- } \\
\text { ness }\end{array}$ & $\begin{array}{c}\Delta \mathrm{E} \\
\text { Firm- } \\
\text { ness } \\
\mathrm{kg}\end{array}$ & $\begin{array}{c}\mathrm{pH} \\
\text { Antho- } \\
\text { cyanin } \\
\mathrm{mg}_{100 \mathrm{~g}^{-1}}\end{array}$ \\
\hline $4.0 \mathrm{j}$ & $24.5 \mathrm{a}$ & $0.8 \mathrm{a}$ & $27.1 \mathrm{a}$ & $10.9 \mathrm{~d}$ & $16.7 \mathrm{~d}$ & $1.4 \mathrm{a}$ & $0 \mathrm{f}$ & $75 \mathrm{~g}$ & $3.8 \mathrm{a}$ & $24.0 \mathrm{f}$ \\
\hline $8.6 \mathrm{~h}$ & $25.3 \mathrm{a}$ & $0.8 \mathrm{a}$ & $26.1 \mathrm{a}$ & $15.6 \mathrm{c}$ & $18.2 \mathrm{a}$ & $1.4 \mathrm{a}$ & $2.4 \mathrm{e}$ & $70 \mathrm{f}$ & $3.7 \mathrm{a}$ & $34.3 \mathrm{e}$ \\
\hline $12,9 \mathrm{~g}$ & $26.4 \mathrm{a}$ & $0.8 \mathrm{a}$ & $24.4 \mathrm{a}$ & $15.6 \mathrm{~b}$ & $17.2 \mathrm{~b}$ & $1.4 \mathrm{a}$ & $3.2 \mathrm{~d}$ & $84 \mathrm{~d}$ & $3.5 \mathrm{a}$ & $34.3 \mathrm{~d}$ \\
\hline $17.2 \mathrm{f}$ & $26.6 \mathrm{a}$ & $0.8 \mathrm{a}$ & $22.7 \mathrm{a}$ & $18.7 \mathrm{a}$ & $16.6 \mathrm{~d}$ & $1.5 \mathrm{ab}$ & $4.7 \mathrm{c}$ & $79 \mathrm{e}$ & $3.8 \mathrm{a}$ & $41.1 \mathrm{a}$ \\
\hline $21.5 \mathrm{e}$ & $26.6 \mathrm{a}$ & $0.8 \mathrm{a}$ & $21.0 \mathrm{a}$ & $17.2 \mathrm{~b}$ & $15.4 \mathrm{e}$ & $2.7 \mathrm{~b}$ & $6.9 \mathrm{~b}$ & $80 \mathrm{~d}$ & $3.8 \mathrm{a}$ & $36.8 \mathrm{~b}$ \\
\hline $25.8 \mathrm{~d}$ & $26.9 \mathrm{a}$ & $0.8 \mathrm{a}$ & $21.6 \mathrm{a}$ & $17.7 \mathrm{~b}$ & $14.4 \mathrm{f}$ & $2.9 \mathrm{~b}$ & $6.7 \mathrm{~b}$ & $91 \mathrm{c}$ & $3.9 \mathrm{a}$ & $34.5 \mathrm{~b}$ \\
\hline $30.1 \mathrm{c}$ & $26.4 \mathrm{a}$ & $0.8 \mathrm{a}$ & $22.9 \mathrm{a}$ & $18.1 \mathrm{a}$ & $13.9 \mathrm{~g}$ & $3.4 \mathrm{c}$ & $6.2 \mathrm{~b}$ & $96 \mathrm{~b}$ & $3.8 \mathrm{a}$ & $39.8 \mathrm{a}$ \\
\hline $34.4 \mathrm{~b}$ & $26.6 \mathrm{a}$ & $0.8 \mathrm{a}$ & $21.7 \mathrm{a}$ & $18.0 \mathrm{a}$ & $14.3 \mathrm{~h}$ & $3.6 \mathrm{c}$ & $7.0 \mathrm{a}$ & $99 \mathrm{a}$ & $3.9 \mathrm{a}$ & $35.2 \mathrm{~b}$ \\
\hline $38.8 \mathrm{a}$ & $26.5 \mathrm{a}$ & $0.8 \mathrm{a}$ & $21.3 \mathrm{a}$ & $18.4 \mathrm{a}$ & $13.5 \mathrm{i}$ & $2.9 \mathrm{~b}$ & $7.3 \mathrm{a}$ & $99 \mathrm{a}$ & $3.9 \mathrm{a}$ & $40.5 \mathrm{a}$ \\
\hline
\end{tabular}


The changes in quality characteristics using increasing blanching water resulted in a higher content of soluble solids and reduced firmness whereas the contents of all other compounds were nonsignificantly different (Table 10). A very detailed description of the effects of blanching, boiling and steaming on glucosinolates, total phenols, total anthocyanins, L-ascorbic acid, antioxidant potential, ferric reducing ability power ferric reducing ability power, oxygen radical absorbance capacity, individual native glucosinolates and losses by blanching, boiling and steaming was found by [9]. Red cabbage leaves are rich in glucosinolates that may be classified as aliphatic, aromatic, $\omega$-methylthioalkyl and heterocyclic compounds [3], that are of special importance because they have anticarcinogenic properties that may result in blocking of phase I and phase II biotransformation enzymes and suppress tumours by apoptosis [4]. Myrosinase or thiogluceride glucohydrolase (E.C. 3.23.1) is the trivial name for the enzyme or group of enzymes that catalyses the hydrolyse of glucosinolates [18] Fenwich and Heaney 1983. The mechanical damage produced by slicing of the red cabbage leaves resulted in mixing of the enzyme molecules with glucosinolates and a row of intermediates that rearranged and resulted in production of compounds in dependence of the composition of the red cabbage leaves such as $\mathrm{pH}$, substrate or availability of minerals [19]. The products from hydrolysis of glucosinolates include isothiocyanates, nitriles, thiocyanates indoles and oxazolidinethiones [4, 24]

Table11. Composition of red cabbage cooked by increasing levels of soluble solids in the cooking water.

\begin{tabular}{|c|c|c|c|c|c|c|c|c|}
\hline $\begin{array}{c}\text { Soluble } \\
\text { solids } \\
\mathrm{g} 100 \mathrm{~g}^{-1}\end{array}$ & $\mathrm{pH}$ & $\begin{array}{c}\text { Acidity } \\
\mathrm{g} 100 \mathrm{~g}^{-1}\end{array}$ & $\begin{array}{c}\text { Antho- } \\
\text { cyanin } \\
\mathrm{mg} 100 \mathrm{~g}^{-1}\end{array}$ & $\begin{array}{c}\text { Firmness } \\
\mathrm{kg}\end{array}$ & $\mathrm{L}$ & Blueness & Redness & $\Delta \mathrm{E}$ \\
\hline $14.3 \mathrm{a}$ & $3.9 \mathrm{a}$ & $0.8 \mathrm{a}$ & $18.2 \mathrm{a}$ & $108 \mathrm{a}$ & $24.3 \mathrm{a}$ & $18.1 \mathrm{a}$ & $-0.6 \mathrm{a}$ & $-0.6 \mathrm{a}$ \\
\hline $17.0 \mathrm{~b}$ & $3.9 \mathrm{a}$ & $0.8 \mathrm{a}$ & $19.8 \mathrm{a}$ & $107 \mathrm{a}$ & $23.8 \mathrm{a}$ & $17.5 \mathrm{a}$ & $0.5 \mathrm{a}$ & $0.5 \mathrm{a}$ \\
\hline $20.0 \mathrm{c}$ & $3.9 \mathrm{a}$ & $0.8 \mathrm{a}$ & $16.7 \mathrm{a}$ & $104 \mathrm{~b}$ & $23.7 \mathrm{a}$ & $18.7 \mathrm{a}$ & $-0.4 \mathrm{a}$ & $-0.4 \mathrm{a}$ \\
\hline $22.0 \mathrm{~d}$ & $3.9 \mathrm{a}$ & $0.8 \mathrm{a}$ & $18.2 \mathrm{a}$ & $100 \mathrm{c}$ & $21.8 \mathrm{a}$ & $17.0 \mathrm{a}$ & $-1.0 \mathrm{a}$ & $-1.0 \mathrm{a}$ \\
\hline $25.3 \mathrm{e}$ & $3.8 \mathrm{a}$ & $0.8 \mathrm{a}$ & $22.3 \mathrm{a}$ & $97 \mathrm{~d}$ & $22.9 \mathrm{a}$ & $19.5 \mathrm{a}$ & $0.0 \mathrm{a}$ & $0.0 \mathrm{a}$ \\
\hline $28.4 \mathrm{f}$ & $3.9 \mathrm{a}$ & $0.8 \mathrm{a}$ & $21.3 \mathrm{a}$ & $94 \mathrm{~d}$ & $21.5 \mathrm{a}$ & $19.6 \mathrm{a}$ & $0.6 \mathrm{a}$ & $0.6 \mathrm{a}$ \\
\hline $30.4 \mathrm{~g}$ & $3.9 \mathrm{a}$ & $0.8 \mathrm{a}$ & $20.8 \mathrm{a}$ & $91 \mathrm{~d}$ & $22.9 \mathrm{a}$ & $18.9 \mathrm{a}$ & $0.2 \mathrm{a}$ & $0.2 \mathrm{a}$ \\
\hline $34.2 \mathrm{~h}$ & $3.8 \mathrm{a}$ & $0.8 \mathrm{a}$ & $20.4 \mathrm{a}$ & $92 \mathrm{~d}$ & $22.5 \mathrm{a}$ & $19.5 \mathrm{a}$ & $0.3 \mathrm{a}$ & $0.3 \mathrm{a}$ \\
\hline $37.4 \mathrm{j}$ & $3.9 \mathrm{a}$ & $0.8 \mathrm{a}$ & $19.7 \mathrm{a}$ & $97 \mathrm{~d}$ & $22.2 \mathrm{a}$ & $17.4 \mathrm{a}$ & $0.7 \mathrm{a}$ & $0.7 \mathrm{a}$ \\
\hline
\end{tabular}

The contents of isothiocyanates and indoles have been implicated to have anticarcinogenic properties [4]) and the data in table 7 shows that increasing heating time by processing of cooked red cabbage resulted in significantly decreases in redness only and the data in table 10 shows that increases in acetic acid in the brine not affected the sugar content or lightness, whereas the increasing levels of acetic acid resulted in higher levels in acidity, redness and yellowness, whereas firmness and $\mathrm{pH}$ decreased significantly. Increasing cooking time from 10 to $60 \mathrm{~min}$ did not affect the contents sugar, $\mathrm{pH}$ or acetic acid in the red cabbage, whereas anthocyanin and firmness decreased significantly with the cooking time. The contents of cabbage and lightness were not affected by increasing cooking time, while blueness decreased and yellowness increased significantly [6]. Increasing cooking time from 10 to 60 min did not affect the contents of soluble solids, $\mathrm{pH}$ or acetic acid in the red cabbage, whereas anthocyanin and firmness decreased significantly with the cooking time. The contents of cabbage and lightness were not affected by increasing cooking time, while blueness decreased and redness increased significantly [2].

Table12. Effects of increasing contents of sugar.

\begin{tabular}{|c|c|c|c|c|c|c|c|c|}
\hline $\begin{array}{c}\text { Sugar } \\
\text { content }\end{array}$ & $\mathrm{pH}$ & $\begin{array}{c}\text { Acetic acid } \\
\text { g } 100 \mathrm{~g}^{-1}\end{array}$ & $\begin{array}{c}\text { Anthocyanin } \\
\mathrm{mg} 100 \mathrm{~g}^{-1}\end{array}$ & $\begin{array}{c}\text { Firmness } \\
\mathrm{kg}\end{array}$ & 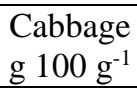 & Lightness & Blueness & Redness \\
\hline 9.6 & $4.0 \mathrm{a}$ & $0.7 \mathrm{a}$ & $37.4 \mathrm{a}$ & $131.0 \mathrm{a}$ & $62.6 a$ & $15.6 \mathrm{a}$ & $10.5 \mathrm{a}$ & $-3.1 f$ \\
\hline 13.9 & $4.0 \mathrm{a}$ & $0.7 \mathrm{a}$ & $37.4 \mathrm{a}$ & $118.4 \mathrm{~b}$ & $63.4 a$ & $15.5 \mathrm{a}$ & $9.9 \mathrm{~b}$ & $-2.7 \mathrm{e}$ \\
\hline 17.8 & $4.0 \mathrm{a}$ & $0.6 \mathrm{a}$ & $36.6 \mathrm{a}$ & $114.4 \mathrm{c}$ & $65.2 \mathrm{a}$ & $14.6 \mathrm{a}$ & $9.2 \mathrm{c}$ & $-2.1 d$ \\
\hline 22.4 & $4.0 \mathrm{a}$ & $0.6 \mathrm{a}$ & $35.5 \mathrm{a}$ & $112.2 \mathrm{~d}$ & $65.0 \mathrm{a}$ & $15.9 \mathrm{a}$ & $9.7 \mathrm{~d}$ & $-1.8 \mathrm{c}$ \\
\hline 26.0 & $4.0 \mathrm{a}$ & $0.6 a$ & $35.8 \mathrm{a}$ & $110.0 \mathrm{e}$ & $64.6 a$ & $15.5 a$ & $9.6 \mathrm{e}$ & $-2.2 b$ \\
\hline 30.1 & $4.0 \mathrm{a}$ & $0.6 \mathrm{a}$ & $34.6 \mathrm{a}$ & 100.0f & $66.2 \mathrm{a}$ & $15.7 \mathrm{a}$ & $9.6 \mathrm{e}$ & $-1.6 \mathrm{a}$ \\
\hline
\end{tabular}

Cooking will cause more thermal degradation to indole glucosinolates (38\%) as compared to aliphatic glucosinolates $(8 \%)$ and canning are the most severe heat treatment that may result in significant thermal degradation $(73 \%)$ of the total amount of glucosinolates [13]. The increasing levels of soluble solids in the recipes resulted in non significantly levels of acidity, anthocyanin, lightness (L), blueness 
(a) increases of redness (a) and decreasing firmness (Table 10). The data in table 10 was obtained by increases using processing water from the previous experiments considered as constant using $7000 \mathrm{~g}$ cabbage and $2000 \mathrm{~g}$ brine composed of a mixture of normal brine as described above and brine with cooking water from previous cooking of red cabbage. Four hundred g cabbage with soluble solids 9.0 $\mathrm{g} 100 \mathrm{~g}^{-1}, \mathrm{pH} 4.0$ were applied and combined with cooking water containing 0 to $900 \mathrm{~g}$ cooking water and from 900 to $\mathrm{g}$ gram tap water. Five samples of $5000 \mathrm{~g}$ cut cabbage $6.8 \mathrm{~mm}$ were cooked in $20 \mathrm{l}$ water for $20,30,40,50$ and $60 \mathrm{~min} 260 \mathrm{~g}$ cooked cabbage were packed with $345 \mathrm{~g}$ brine kept at $70^{\circ} \mathrm{C}$ and pasteurised at $85^{\circ} \mathrm{C}$ for and stored at $12{ }^{\circ} \mathrm{C}$ for 3 months until analysis After removal of the outer leaves by hand were the remaining leaves cut by hand into $0.5 \mathrm{~cm}$ pieces and $2000 \mathrm{~g}$ cabbage cuttings were cooked in a stainless steel water bath with $7000 \mathrm{~g}$ tap water. After cooking were the cabbage pieces cooled in tap water cooled to $75{ }^{\circ} \mathrm{C}$ and transferred into $580 \mathrm{~cm}^{3}$ glass jars cold water net and cooled to $75^{\circ} \mathrm{C}$ in a nylon net transferred from the cooking pot cooled using in tap water pieces cooled pooling cooking pot. The raw materials from this experiment included application of cabbage leaves from the cultivar 'Autoro'. Five kg cabbage heads from each cultivar without stalk were cut randomly into $6.8 \mathrm{~mm}$ slices, mixed carefully and $5000 \mathrm{~g}$ cabbage cuttings were heated in 201 tap water kept at $94{ }^{\circ} \mathrm{C}$ for $20,30,4050$ and $60 \mathrm{~min}$. After cooling to $12^{\circ} \mathrm{C}$ in tap water were three samples with $260 \mathrm{~g}$ cooked cabbage slices packed in $580 \mathrm{~mm}$ glass jars with $345 \mathrm{~g}$ brine kept at $70^{\circ} \mathrm{C}$. And finally were the glass jars cooled for $5 \mathrm{~min}$ in tap water at $60^{\circ} \mathrm{C}$ and $30 \mathrm{~min}$ in tap water until storage at $12^{\circ} \mathrm{C}$ for three months. Samples of raw cabbage cuttings stored at $-25^{\circ} \mathrm{C}$ until red cabbage study shows all anthocyanins are not created equal analysis. The brine were processed from $2275 \mathrm{~g}$ sugar, $65 \mathrm{~g}$ acetic acid, K sorbate $6.5 \mathrm{~g} 20 \mathrm{w} / \mathrm{w} \%$ acetic acid, $13.5 \mathrm{~g}$ w/w Na-benzoate and $4140 \mathrm{~g}$ tap water. The jars were rotated by hand once each week during the first month of storage. Data from storage of red cabbage pieces from the cultivars 'Marne' and 'Ruby Perfection' from one harvest time $13^{\text {th }}$ September and 'Autoro' six times from 27 September to 13 December. A number of epidemiological studies have identified an inverse association between consumption of vegetables and the risk of colon and rectal cancer. Animal studies have shown that changes in enzyme activities cause damage resulting from consumption of Brassica vegetables or isothiocyanates, that are the breakdown products in the human body. Mechanistic studies have begun to identify the ways in which the compounds may exert their protective action but the relevance of these studies to protective effects in the human alimentary tract is as yet unproven. Studies with a number of specific isothiocyanates have suggested mechanisms that might be the basis of their chemoprotective effects [4]. The concentration and composition of the GLSs in different plants, but also within a plant in the seeds, roots or leaves, may vary greatly and cause changes during plant development. Total aliphatic and indole glucosinolates were significantly modified by all cooking treatments but not by steaming. In general, the steaming led to the lowest loss of total glucosinolates, while stir-frying and stir-frying/boiling presented the highest loss. Stir-frying and stir-frying-boiling are the two most popular methods for most homemade dishes that may cause great losses of chlorophyll, soluble protein, soluble sugar, vitamin $\mathrm{C}$, and glucosinolates, but the steaming method appears to be the best in retention of the nutrients in cooking broccoli. During the food production chain from sowing, picking [16], storage and processing may the composition of glucosinolates change significantly [22], 23]. The results showed that all cooking treatments, except steaming, caused significant losses of chlorophyll and vitamin $\mathrm{C}$ and significant decreases of total soluble proteins and soluble sugars. Total aliphatic and indole glucosinolates were significantly modified by all cooking treatments but not by steaming. In general, the steaming led to the lowest loss of total glucosinolates, while stir-frying and stir-frying or boiling presented the highest losses. Stir-frying and stir-frying/boiling, the two most popular methods for most homemade dishes in China may cause great losses of chlorophyll, soluble protein, soluble sugar, vitamin $\mathrm{C}$, and glucosinolates, but the steaming method appears to be the best in retention of the nutrients in cooking broccoli. The various methods used by processing of red cabbage may result in severe significantly reductions of bioactive compounds including carotenoids, anthocyanins and phenolic compounds [15]. Cooking techniques improve the $\mathrm{g}$ and freezing of selected cruciferous levels of bioactive compounds and antioxidant activity in kale and red cabbage. Blanching and frozen storage of cauliflower resulted in significantly decreases in aliphatic and indole glucosinolates by 31 and 37 percent and the contents of 1-ascorbic acid 19 percent, total phenols 15 , anthocyanins were reduced by 19, 15, 38, 16, and 28 per cent [9]. Effects of blanching, boiling of brussel sprouts, white and green cauliflower, broccoli, and curly kale on their contents of glucosinolates contents were determined. It was found that blanch- 
ing and cooking of these vegetables led to considerable losses of total glucosinolates from 2.7 to 30.0 per cent and from 35.3 to 72.4 per cent, respectively [9].

Table13. Effects of acetic acid on soluble solids, anthocyanin, firmness, cabbage and colour.

\begin{tabular}{|c|c|c|c|c|c|c|c|c|}
\hline $\begin{array}{c}\text { Acetic acid } \\
\text { w/w\% }\end{array}$ & $\begin{array}{c}\text { Soluble solids } \\
\mathrm{g} 100 \mathrm{~g}^{-1}\end{array}$ & $\begin{array}{c}\text { Anthocyanin. } \\
\mathrm{mg} 100 \mathrm{~g}^{-1}\end{array}$ & $\mathrm{pH}$ & $\begin{array}{c}\text { Firmness } \\
\mathrm{kg}\end{array}$ & $\begin{array}{c}\text { Cabbage } \\
\mathrm{g} 100 \mathrm{~g}^{-1}\end{array}$ & $\mathrm{~L}$ & Blueness & Redness \\
\hline $0.3 \mathrm{a}$ & $20.6 \mathrm{a}$ & $63.6 \mathrm{a}$ & $4.4 \mathrm{a}$ & $97.6 \mathrm{a}$ & $81.5 \mathrm{a}$ & $15.6 \mathrm{a}$ & $6.2 \mathrm{f}$ & $-0.8 \mathrm{f}$ \\
\hline $0.5 \mathrm{a}$ & $20.7 \mathrm{a}$ & $46.3 \mathrm{a}$ & $4.1 \mathrm{~b}$ & $91.5 \mathrm{~b}$ & $80.9 \mathrm{a}$ & $16.86 \mathrm{~b}$ & $9.1 \mathrm{e}$ & $-0.15 \mathrm{e}$ \\
\hline $0.7 \mathrm{a}$ & $20.6 \mathrm{a}$ & $47.6 \mathrm{a}$ & $4.0 \mathrm{c}$ & $89.3 \mathrm{~d}$ & $80.5 \mathrm{~b}$ & $16.4 \mathrm{c}$ & $10.9 \mathrm{~d}$ & $0.7 \mathrm{~d}$ \\
\hline $0.9 \mathrm{a}$ & $20.6 \mathrm{a}$ & $46.3 \mathrm{a}$ & $3.8 \mathrm{~d}$ & $90.8 \mathrm{c}$ & $78.6 \mathrm{c}$ & $16.9 \mathrm{~d}$ & $10.7 \mathrm{c}$ & $0.5 \mathrm{c}$ \\
\hline $1.1 \mathrm{a}$ & $20.8 \mathrm{a}$ & $46.3 \mathrm{a}$ & $3.8 \mathrm{~d}$ & $87.2 \mathrm{~d}$ & $79.1 \mathrm{c}$ & $17.3 \mathrm{e}$ & $12.7 \mathrm{~d}$ & $1.1 \mathrm{~b}$ \\
\hline $1.3 \mathrm{a}$ & $21.3 \mathrm{a}$ & $46.3 \mathrm{a}$ & $3.8 \mathrm{~d}$ & $76.0 \mathrm{e}$ & $79.1 \mathrm{c}$ & $17.2 \mathrm{f}$ & $13.5 \mathrm{a}$ & $1.4 \mathrm{a}$ \\
\hline
\end{tabular}

The data in table 14 shows that increasing cooking time not affected $\mathrm{pH}$, acetic acid, anthocya-nin, cabbage or lightness, whereas firmness and blueness decreased and redness increased sig-nificantly and table 8 shows the results from linear regression analyses. On the basis of this it was concluded that the most important changes by processing are that firmness decreases with increasing acetic acid, increasing soluble solids and processing time. Greenness and yellowness increased by increasing acetic acid. Anthocyanin and yellowness decreased and increased re-spectively by processing (Table 14). The concentration and composition of the glucosinolates in different plant tissues, such as seeds, roots or leaves may occur during plant development [24]. Furthermore, the effects of various factors in the supply chain of Brassica vegetables including breeding, cultivation, storage and processing on intake and bioavailability of GLSs must be dis-cussed extensively. On the basis of these animal studies have it been shown that changes in en-zyme activities may cause damage resulting from consumption of isothiocyanates, that are the breakdown products in the human body. These results in identification of ways in which the relevance of these studies to protective effects in the human alimentary tract has to be consid-ered on the basis of more research [24]. Increases in the sugar content, constant pH, acetic acid, anthocyanin, cabbage, lightness resulted in decreasing firmness [5].

Table14. Cabbage quality characteristics of converted and non-converted samples.

\begin{tabular}{|l|l|c|c|c|c|c|c|c|c|c|c|c|}
\hline & Contents & \multicolumn{9}{|c|}{ Non converted } & \multicolumn{6}{c|}{ Converted } \\
\hline & & $\mathrm{a}$ & $\mathrm{b}$ & $\mathrm{c}$ & $\mathrm{d}$ & $\mathrm{e}$ & $\mathrm{a}$ & $\mathrm{B}$ & $\mathrm{c}$ & $\mathrm{d}$ & $\mathrm{e}$ \\
\hline Weight, g & & 850 & 850 & 850 & 850 & 850 & 850 & 850 & 850 & 850 & 850 \\
\hline Brine, \% & & $15.2 \mathrm{e}$ & $16.9 \mathrm{~d}$ & $18.7 \mathrm{c}$ & $25.5 \mathrm{~b}$ & $24.8 \mathrm{a}$ & $16.8 \mathrm{~b}$ & $22.1 \mathrm{a}$ & $20.1 \mathrm{a}$ & $16.2 \mathrm{~b}$ & $14.4 \mathrm{c}$ \\
\hline Firmness, kg & Cabbage & $0.9 \mathrm{a}$ & $71 \mathrm{~d}$ & $74 \mathrm{c}$ & $84 \mathrm{~b}$ & $89 \mathrm{a}$ & $126 \mathrm{a}$ & $113 \mathrm{~b}$ & $108 \mathrm{c}$ & $103 \mathrm{~d}$ & $100 \mathrm{e}$ \\
\hline Acidity g 100 g & -1 & Cabbage & $0.4 \mathrm{a}$ & $0.5 \mathrm{a}$ & $0.6 \mathrm{a}$ & $0.4 \mathrm{a}$ & $0.5 \mathrm{a}$ & $0.3 \mathrm{a}$ & $0.4 \mathrm{a}$ & $0.4 \mathrm{a}$ & $0.4 \mathrm{a}$ & $0.4 \mathrm{a}$ \\
\hline & Brine & $0.5 \mathrm{a}$ & $0.5 \mathrm{a}$ & $0.4 \mathrm{a}$ & $0.4 \mathrm{a}$ & $0.5 \mathrm{a}$ & $0.3 \mathrm{a}$ & $0.3 \mathrm{a}$ & $0.3 \mathrm{a}$ & $0.4 \mathrm{a}$ & $0.4 \mathrm{a}$ \\
\hline Sol.sol., g 100 g & -1 & Cabbage & $16.6 \mathrm{e}$ & $17.7 \mathrm{~d}$ & $19.2 \mathrm{c}$ & $20.2 \mathrm{~b}$ & $22.2 \mathrm{a}$ & $17.6 \mathrm{~b}$ & $17.3 \mathrm{~b}$ & $17.9 \mathrm{~b}$ & $18.4 \mathrm{a}$ & $18.5 \mathrm{a}$ \\
\hline & Brine & $17.1 \mathrm{e}$ & $18.0 \mathrm{~d}$ & $19.5 \mathrm{c}$ & $21.3 \mathrm{~b}$ & $22.6 \mathrm{a}$ & $17.7 \mathrm{c}$ & $18.2 \mathrm{~b}$ & $18.6 \mathrm{~b}$ & $18.9 \mathrm{~b}$ & $19.4 \mathrm{a}$ \\
\hline Antho. mg 100g & -1 & Cabbage & $40.2 \mathrm{a}$ & $38.1 \mathrm{~b}$ & $35.7 \mathrm{c}$ & $32.2 \mathrm{~d}$ & $28.5 \mathrm{e}$ & $39.4 \mathrm{a}$ & $39.5 \mathrm{a}$ & $38.7 \mathrm{a}$ & $39.2 \mathrm{a}$ & $39.4 \mathrm{a}$ \\
\hline “ & Brine & $34.9 \mathrm{a}$ & $33.7 \mathrm{a}$ & $31.5 \mathrm{a}$ & $28.7 \mathrm{~b}$ & $25.6 \mathrm{~b}$ & $34.7 \mathrm{a}$ & $35.3 \mathrm{a}$ & $34.9 \mathrm{a}$ & $32.7 \mathrm{a}$ & $36.2 \mathrm{a}$ \\
\hline Greenness, a & Cabbage & $16.1 \mathrm{c}$ & $18.2 \mathrm{~b}$ & $18.4 \mathrm{~b}$ & $20.3 \mathrm{a}$ & $20.7 \mathrm{a}$ & $17.3 \mathrm{a}$ & $18.6 \mathrm{a}$ & $17.3 \mathrm{a}$ & $17.0 \mathrm{a}$ & $16.9 \mathrm{a}$ \\
\hline Yellowness, b & Cabbage & $-3.3 \mathrm{e}$ & $-2.4 \mathrm{~d}$ & $-2.2 \mathrm{c}$ & $-1.1 \mathrm{~b}$ & $-1.7 \mathrm{a}$ & $-4.0 \mathrm{~b}$ & $-3.6 \mathrm{a}$ & $-3.3 \mathrm{a}$ & $-3.4 \mathrm{a}$ & $-3.3 \mathrm{a}$ \\
\hline
\end{tabular}

Effects of cooking time on firmness and surface colour. The results from this research showed that firmness decreased significantly with increasing acetic acid concentration whereas both redness and yellowness increased with increasing concentration of acetic acid. Firmness $)=100.8-16.5$ acetic acid; $r=0.81$; redness $a=5.09+6.9$ acetic acid; $r=0.96$ and yellowness $b=-1.33+2.2$ acetic acid; $r=$ 0.99. Increasing cooking time resulted in constant sugar, $\mathrm{pH}$, and acetic acid, cabbage and lightness, while anthocyanin, firmness and redness $(\alpha)$ decreased significantly and yellowness increased significantly during cooking. During the food production chain from sowing, picking, storage and processing may the composition of glucosinolates change significantly [4,16, 22, 23]. Decreasing greenness and yellowness resulted in significantly decreasing firmness, decreases in redness and increasing yellowness (Table 15). Table 14 shows the results from using previously liquids by processing of red cabbage pieces with solids $9.0 \mathrm{~g}$ at $\mathrm{pH}$ 3.97. Four hundred g red cabbage pieces with $\mathrm{pH} 3.97$ and prcessing liquids from prevous cooking of red cabbage. $400 \mathrm{~g}$ cabbage was boiled in $900 \mathrm{~g}$ boiling water containing from 0 to $900 \mathrm{~g}$ processing liquids and 900 to $0 \mathrm{~g}$ tap water. The contents of antho-

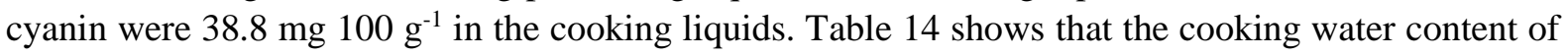




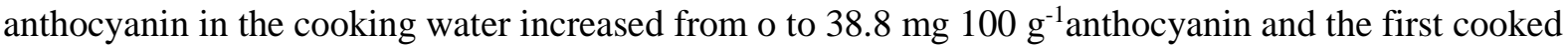

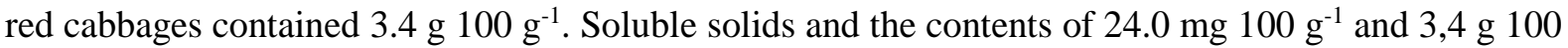

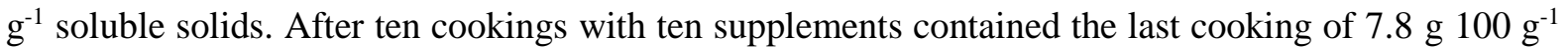
soluble solids and $40.5 \mathrm{mg} 100 \mathrm{~g}^{-1}$ anthocyanin. Lightness, greenness decreased while yellowness inceased due to the contents in the supplied samples. $\Delta \mathrm{E}$ and firmness increases, $\mathrm{pH}$ was constant and the contents of soluble solids and anthocyanin increased significantly with increasing sample number.

Table15. Effects of increasing cooking time on quality characteristics.

\begin{tabular}{|c|c|c|c|c|c|c|c|c|c|}
\hline $\begin{array}{l}\text { Cooking } \\
\text { min }\end{array}$ & $\begin{array}{l}\text { Sugar } \\
\text { g } 100 \mathrm{~g}^{-1}\end{array}$ & $\mathrm{pH}$ & $\begin{array}{l}\text { Acetic acid } \\
\text { g } 100 \mathrm{~g}^{-1}\end{array}$ & $\begin{array}{c}\text { Anthocyanin } \\
\mathrm{mg} 100 \mathrm{~g}^{-1}\end{array}$ & $\begin{array}{c}\text { Firmness } \\
\mathrm{kg}\end{array}$ & $\begin{array}{l}\text { Cabbage } \\
\text { g } 100 \mathrm{~g}^{-1}\end{array}$ & $\mathrm{~L}$ & $\mathrm{a}$ & b \\
\hline 10 & $20.8 \mathrm{a}$ & $4.0 \mathrm{a}$ & $0.6 \mathrm{a}$ & $39.5 a$ & $361.0 \mathrm{a}$ & $64.6 a$ & $17.0 \mathrm{a}$ & $14.1 \mathrm{a}$ & $-0.4 a$ \\
\hline 15 & $20.9 a$ & $4.0 \mathrm{a}$ & $0.6 \mathrm{a}$ & $40.1 b$ & $256.0 \mathrm{~b}$ & $66.4 \mathrm{a}$ & $17.0 \mathrm{a}$ & $14.4 \mathrm{a}$ & $-0.1 \mathrm{a}$ \\
\hline 25 & $20.9 a$ & $4.0 \mathrm{a}$ & $0.6 \mathrm{a}$ & $39.2 \mathrm{a}$ & $223.5 \mathrm{c}$ & $67.1 \mathrm{a}$ & $17.1 \mathrm{a}$ & $14.5 \mathrm{a}$ & $-0.1 b$ \\
\hline 30 & $21.3 b$ & $4.0 \mathrm{a}$ & $0.6 \mathrm{a}$ & $37.4 \mathrm{c}$ & $112.5 \mathrm{~d}$ & $68.3 a$ & $16.3 b$ & $11.9 \mathrm{~b}$ & $0.2 \mathrm{~b}$ \\
\hline 40 & $21.2 \mathrm{~b}$ & $4.0 \mathrm{a}$ & $0.6 \mathrm{a}$ & $34.6 \mathrm{c}$ & $89.8 \mathrm{c}$ & $67.3 \mathrm{a}$ & $17.2 \mathrm{a}$ & $13.4 \mathrm{~b}$ & $0.9 \mathrm{~b}$ \\
\hline 50 & $21.4 \mathrm{~b}$ & $4.0 \mathrm{a}$ & $0.6 a$ & $35.8 \mathrm{c}$ & $75.4 \mathrm{f}$ & $68.0 \mathrm{a}$ & $17.4 \mathrm{a}$ & $12.0 \mathrm{~b}$ & $0.6 \mathrm{~b}$ \\
\hline 60 & $20.1 \mathrm{a}$ & $4.0 \mathrm{a}$ & $0.6 \mathrm{a}$ & $30.9 \mathrm{~d}$ & $61.6 \mathrm{~g}$ & $68.7 \mathrm{a}$ & $18.3 \mathrm{a}$ & $11.4 \mathrm{~b}$ & $0.4 \mathrm{a}$ \\
\hline
\end{tabular}

The data in table 16 shows that the composition of two samples of red cabbage and brine were completely equilibrated. A number of epidemiological studies have identified an inverse association between consumption of these vegetables and the risk of colon and rectal cancer. Animal studies have shown that changes in enzyme activities may cause damage resulting from consumption of Brassica vegetables or isothiocyanates that are the breakdown products in the human body. Mechanistic studies have begun to identify the ways in which the compounds may exert their protective action but the relevance of these studies to protective effects in the human alimentary tract is as yet unproven. Studies with a number of specific isothiocyanates have suggested mechanisms that might be the basis of their chemo protective effects. The concentration and composition of the GLSs in different plants, but also within a plant in the seeds, roots or leaves, can vary greatly and also changes during plant development. Furthermore, the effects of various factors in the supply chain of Brassica vegetables including breeding, cultivation, storage and processing on intake and bioavailability of GLSs are discussed in

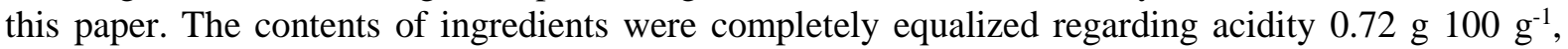

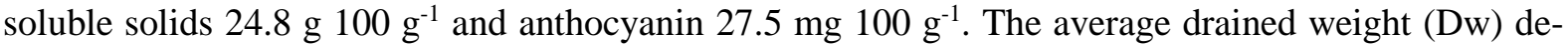
creased significantly linearly with cooking time $\mathrm{Dw}=313-0.123 \mathrm{~min} . \mathrm{r}=0.98$ and the average firmness decreased exponentially with cooking time. Total aliphatic and indole glucosinolates were significantly modified by all cooking treatments but not by steaming. In general, the steaming led to the lowest loss of total glucosinolates, while stir-frying and stir-frying/boiling presented the highest loss. Stir-frying and stir-frying/boiling are the two most popular methods for most homemade dishes that may cause great losses of chlorophyll, soluble protein, soluble sugar, vitamin C, and glucosinolates, but the steaming method appears to be the best in retention of the nutrients in cooking broccoli. Processing of red cabbage by increasing contents of acetic acid at constant levels of soluble solids, anthocyanin and $\mathrm{pH}$ resulted in decreasing firmness and cabbage, whereas lightness, blueness, and redness increased.

\section{REFERENCES}

[1] Charron, C.S., Clevidence, B. A., Britz, S. J. Novotny J. A. 2007. Effect of dose size on bioavailability of acylated and nonacylated anthocyanins from red cabbage (Brassica oleracea L. var. capitata). J. Agric. Food Chem. 55, 5354-5362.

[2] Podsędek A., Majewska I., Kucharska A. Z., Podsędek, A., Majewsk I., Kucharska A. Z. 2017. Inhibitory potential of red cabbage against digestive enzymes linked to obesity and type 2 diabetes. J. Agric. Food Chem. 65, 7192-7199.

[3] Fahey, J. W., Zalcmann A.T., Talalay, P. 2001. The chemical diversity and distribution of glucosinolates and isothiocyanates among plants. Phytochem. 56, 5-51.

[4] Mithen R.F., Dekker, M., Verkerk, R., Rabot, S., Johnson I.T. 2000. The nutritional significance of biosynthesis and bioawailability of glucosinolates in human foods. J. Sci. Food Agric. 80, 967-984.

[5] Xiao, D., Srivastava, S.K,, Lew K.L. Zeng Y., Herschberger, P., Johnson, C.S. 2003. Allyl isoisothiocyanate a constituent of cruciferous vegetables, inhibits proliferation of human prostate cancer cells by causing G2/M arrest and inducing apoptosis. Carcinogenesis. 24, 891-897. 
[6] Ahmadiani, N., Robbins, R.J., Collins, T.M., Giusti, M.M. 2014a. Anthocyanins contents, profiles, and color characteristics of red cabbage extracts from different cultivars and maturity stages. J. Agric. Food Chem. 62, 7524-7531.

[7] Ahmadiani, N., Robbins R.J., Collins T.M., Giusti, M.M., 2014b. Inhibitory potential of red cabbage against digestive enzymes linked to obesity and Type 2 Diabetes. J. Agric. Food Chem., 2017, 65, 71927199.

[8] Kaack, K. 2018.. Growing and picking of green beans. Int. J. Foresty. Hort. 4, 25-37. Effects of different cooking methods on health-promoting compounds of broccoli. J. Zhejiang Univ. Sci. 10: 580-588.

[9] Volden J.Borge,G.I.A, Bengtsson, G.B., Hansen, M.,Thygesen, I.E., Wicklunf, T. 2008. Effect of thermal treatment on glucosinolates and antioxidant-treated parameters in red cabbage (Brassica oleraceae L. ssp capitata f. rubra. Food Chem. 109, 595-605.

[10] Amin, I. , Lee, WY. 2005. Effect of thermal treatment on glucosinolates and antioxidant-related parameters in red cabbage Brassica oleracea L ssp capitata f. rubra 2008. Food Chem. 10, 595-605.

[11] Wiczkowski, W., Szawara-Nowak, D., Topolska, J. 2012. Red cabbage anthocyanins: Profile, isolation, identification and antioxidant activity. Food Res. Int. 51, 303-309.

[12] Oerlemans, K., Barrett, D.M., Suades, C.B., Verkerk, Dekker, M. 2006. Thermal degradation of glucosinolates in red cabbage. Food Chem. 95,19-29.

[13] Oerlemans, K., Barrett, D. M., Suades, C. B., Verkerk R., Dekker M. 2006. Thermal degradation of glucosinolates in red cabbage. Food Chem. 95, 19-29.

[14] Verkerk, R., Schreiner M., Krumbein, A., Ciska E. Holst, B. 2015. Glucosinolates in Brassica vegetables: The influence of the food supply chain on intake, bioawailability and human health of the food supply chain on intake, bio awailability on human health. The influence

[15] Vos de R.H., Blijleven, W.G. 2004; The effect of processing conditions on glucosinolates in cruciferous vegetables. Z. Lebensm.-Untersuchung Forsch. 187, 525-529.

[16] Verkerk R, Dekker M. 2004. Glucosinolates and myrosinase activity in red cabbage (Brassica oleracea L. var. Capitata f. rubra DC.) after various microwave treatments. J Agric Food Chem., 52, 7318-7323.

[17] Verkerk, R., Schreiner M,. Krumbein, A., Ciska, E. 2009. Glucosinolates in Brassica vegetables: The influence of the food supply chain on intake, bioavailability and human health. Glucosinolates in Brassica vegetables Mol., Nutr. Food Res. 53, Suppl 2: S219.

[18] Fenwick GR, Heaney RK, Mullin WJ. 1983. Glucosinolates and their breakdown products in food and food plants. Crit. Rev. Food Sci. Nutr. 18:123-201.

[19] Dekker, M., Hennig, K., Verkerk, R. 2009. Differences in thermal stability of glucosinolates in five brassica gluconosilates. Czech. J. Food Sci. 27, S85-S88.

[20] Bayblis, A., Little, A.D., Spomer, A.D., Berber-Jimenez, M.D. 1994. Anthocyanin pigments: comparison of extract stability J. Food Sci. 59, 1219-1221.

[21] Cieślik, E., Leszczyńska T., Filipiak-Florkiewicza E. A., Paweł, S. M. Pisulewski P. M. 2007. Effects of some technological processes on glucosinolate contents in cruciferous vegetables. Food Chem., 976-981.

[22] Cieślik Ewa, Leszczyńska, T., Florkiewicz, A. F., Sikora E., Pisulewski P. M. 2007. Cieślik, E., Leszczyńska T., Filipia -Florkiewicz A., Sikora, E.,Pisulewsk P. M. 2007. Effects of some technological processes on glucosinolate contents in cruciferous vegetables Food Chem. 105, 976-981

[23] Verkerk, R., Dekker, M., 2003 European Journal of Nutrition, 42, 67-72). Many epidemiological studies have tried to associate the intake of certain food products with a reduced risk for certain disease (Dekker et al., 2009).

[24] Ahmadiani N, Didier Socquet-Juglard $\dagger$, Alexandra A. Bennett $\dagger$, David C. Manns, Anna Katharine Mansfield, A.K., Robbins, R.J., Collins T. M. 2016, Effects of growth temperature and postharvest cooling on anthocyanin profiles in juvenile and mature Brassica oleracea J. Agric. Food Chem., 64, 1484-1493.

Citation: K. Kaack, "Industrial Processing of Cooked Red Cabbage Pieces (Brassica Oleracea L.) ", International Journal of Forestry and Horticulture (IJFH), vol. 5, no. 2, pp. 1-13, 2019. Available: DOI: http://dx.doi.org/10.20431/2454-9487.0502001

Copyright: () 2019 Authors. This is an open-access article distributed under the terms of the Creative Commons Attribution License, which permits unrestricted use, distribution, and reproduction in any medium, provided the original author and source are credited. 